\title{
Business as Usual?
}

\section{The Impact of Anti-Russian Sanctions Introduced by the U.S. on the Foreign Investment Activity of Russian Oil and Gas TNCs: The Lukoil and Rosneft Investment Strategy of Russian Oil and Gas TNCs During the Sanctions Period ${ }^{1}$}

\author{
N. Ivanova, S. Lavrov
}

Natalia Ivanova - PhD in Economic Sciences, Head of Bilateral co-operation Division, International Affairs Department, Russian Energy Agency the Ministry of Energy of the Russian Federation (Federal State Budget Organization); bldg. 1, 40 Schepkina Str., Moscow, 129110, Russian Federation; E-mail: na_iv@mail.ru

Sergey Lavrov - PhD in Economic Sciences, Professor, Head of International Business Section Department of World Economy National Research University Higher School of Economics; 17 Malaya Ordynka Str., Moscow, 101000, Russian Federation; E-mail: lavrovsn@mail.ru

\begin{abstract}
This article examines the impact of anti-Russian sanctions introduced by the U.S., including the sanctions package signed on 10 August 2017, on the foreign investment activity of Russian oil and gas transnational corporations (TNCs) such as Lukoil and Rosneft in particular. The authors examine the American sanctions against Russia and identify the possible consequences of such restrictions for the development of the Russian oil and gas sector and foreign capital expansion of Russian oil and gas majors; the authors also analyze the foreign investment activity of Lukoil and Rosneft under the sanctions regime.
\end{abstract}

Key words: sanctions; Russian oil and gas sector; foreign investment activity of Russian oil and gas TNCs; Lukoil; Rosneft

For citation: Ivanova N., Lavrov S. (2019) The Impact of Anti-Russian Sanctions Introduced by the U.S. on the Foreign Investment Activity of Russian Oil and Gas TNCs: The Lukoil and Rosneft Investment Strategy of Russian Oil and Gas TNCs During the Sanctions Period. International Organisations Research Journal, vol. 14, no 1, pp. 126-144 (in English). DOI: 10.17323/1996-7845-2019-01-08

${ }^{1}$ The editorial board received the article in June 2018. 


\section{Introduction}

The sanctions imposed against Russia by the U.S. in 2014 and expanded in 2017 are intended to destabilize the development of the Russian oil and gas industry as a whole and are primarily aimed at weakening Russia's position in the international energy arena. Implementation of the sanctions regime imposes on the key Russian oil and gas companies new strategic objectives for current and long-term development, bringing to the fore the issue of further opportunities and prospects for their foreign investment activities.

On 12 September 2014 the U.S. Department of the Treasury introduced a package of sanctions against the energy, financial and military sectors of Russian economy. U.S. sanctions were introduced by Executive Order 13662 signed by the U.S. President Barack Obama. The sanctions package included four directives - measures against Russia's oil sector are set out in Directives 2 and 4.

According to Directive 4, American companies are prohibited from providing direct or indirect exportation supplies, re-exportation of goods, services (except for financial services) and technologies to Russian oil and gas companies such as Gazprom, Novatek, Rosneft, Lukoil, Surgutneftegaz and Gazprom Neft (their properties or their interests in property) which could be used in support of oil exploration and production for deepwater, shale or Artic offshore projects claimed by the Russian Federation [United States Treasury, 2014b].

Directive 2 imposes "restrictions on any transaction operations, funding and any other operations on new tax obligation, of longer than 90 days maturity" [United States Treasury, 2014a] for individuals and companies listed in the directive, their property and their interests in property. The list of sanctioned companies includes Rosneft, Novatek, Transneft and Gazprom Neft, the last two of which appeared in this list for the first time. These financial restrictions are not applied to Lukoil, Surgutneftegaz or Gazprom.

In sum, sanctioned Russian companies were cut off from oil and gas equipment, services and technologies (even from countries of origin other than the U.S.) in any case in which a supplier was aware that the equipment would be used in support of oil exploration and production in deepwater projects, Arctic offshore projects or any other shale formations. In particular, the embargo applies to drilling, geophysical, geological, logistics and management services, as well as computer modeling and modern mapping technologies.

American companies must abide by the export restrictions to Russia regardless of their location and dispatch of goods. They were given only 14 days to finish the delivery of goods and services under existing contracts and agreements.

Clarifications to certain definitions were added to the updated sanctions list in the executive order of 12 September. Deepwater projects were defined as oil exploration and production in waters deeper than 500 feet; Arctic offshore projects were defined as those with a potential to produce oil in areas above the Arctic Circle that involve drill- 
ing operations originating offshore; shale projects were defined as those with a potential to produce oil from resources located in shale formations. Moreover, the geographical scope of sanctions was clarified to include the territory of the Russian Federation and its maritime territories, including the continental shelf.

An important feature of Directive 4 is that the prohibition on the provision, exportation (direct and indirect), re-exportation of goods, services (except for financial) and technologies extends to exploration and production in deepwater, shale and Arctic offshore projects, irrespective of whether the project has the potential to produce gas. Prohibitions do not apply if projects only produce gas. Therefore, sanctions apply to oil-gas, gas-oil, gas-condensate oil and oil-gas condensate projects.

On 2 August 2017, U.S. President Donald Trump signed into law the Countering America's Adversaries Through Sanctions Act (H.R. 3364) [United States Treasury, 2017] - hereafter, the Sanctions Act - which had been passed by both houses of Congress in the previous month. In general, the act is a primarily political document, focused on tightening the sanctions regime against Iran, Russia and North Korea, and on limiting president's authority to lift sanctions without congressional approval.

In the section regarding the Russian Federation, the document includes an assessment of Russia's foreign policy and a list of political, military and economic measures to counteract Russia's policy aims by putting pressure on Russia's fuel and energy complex in order to destabilize the Russian economy. Adoption of this law created new challenges for the Russian government and Russian companies to overcome.

The crucial feature of the Sanctions Act for Russia appears in the section entitled "Sanctions with Respect to the Russian Federation and Combating Terrorism and Illicit Financing."

On the legislative level the act enforces sanctions imposed by President Barack Obama under Executive Order No 13660 (on 6 March 2014), Executive Order No 13661 (on 6 March 2014), Executive Order No 13662 (on 6 March 2014), Executive Order No 13694 (on 1 April 2015) including the Appendix on 29 December 2016, Executive Order No 13685 (19 December 2014) including the Appendix on 29 December 2016, the Ukraine Freedom Support Act (on 18 December 2014), and Directive 41 (on 26 July 2016) about cybersecurity incidents relevant to the vital national interests of the United States. A report prepared by the Central Intelligence Agency (CIA), the Federal Bureau of Investigation (FBI) and the National Security Agency (NSA) entitled "Accessing Russian Activities and Intentions in Recent U.S. Elections" (on 6 January 2017) was taken into consideration.

In general, the new legislation with respect to Russia codifies and modifies existing anti-Russian sanctions enshrined in prior directives, including restrictions on certain energy projects of the Russian Federation and financing for certain sectors of Russian economy. It also applies new sanctions on strategic sectors of the Russian economy, in particular, mining, metals and transport industries including shipping and railways. Importantly, the president must receive congressional approval before taking any action to ease, suspend or lift sanctions. 
The Sanctions Act enabled Congress to significantly restrict the president's authority. After adopting this document, any attempt by the president to terminate or waive restrictions for individuals and companies listed in the sanctioned list must be submitted to the Congress. For example, according to the Ukraine Freedom Support Act relating to defense and energy sectors of Russia referenced in Section 229, in order to introduce new sanctions the president must notify the appropriate congressional committees in writing.

According to Section 222 the president can terminate the application of sanctions provided for in Executive Order No 13660, No 13661, No 13662 and No 13685, if the president submits to the appropriate congressional committees a written determination that rejection is in the vital national security interests of the United States, or gives a certification that the government of the Russian Federation is taking steps to implement the Minsk Agreement - meant to address the ongoing conflict in eastern Ukraine and signed in Minsk, Belarus on 11 February 2015 by the leaders of Ukraine, Russia, France and Germany - as well as any successor agreements that are agreed to by the government of Ukraine. These kinds of amendments help the U.S. Congress gain more control over the government's sanctions policy.

Concerning the fuel and energy complex, the Sanctions Act envisages extending the restrictions with regard to cooperation of American nationals and companies ("United States persons") with Russians through various amendments. Executive Order 2 of 12 September 2014 reduces minimal financing maturity from 90 to 60 days for energy companies falling under the sanctions (Rosneft, Transneft, Gazprom Neft, Novatek). That said, most experts argue that the amendment's influence on the activity of key Russian energy companies will not be significant because the long-term financing was greatly reduced earlier. Executive Order 4 of 12 September 2014 extended the range of shale, deepwater, and Arctic offshore projects subject to the restrictions and direct prohibition for participation by United States persons. As a result, the sanction regime encompasses all projects, including those abroad, of PSJC Gazprom, PSJC Gazprom Neft, PSJC Lukoil, PSJC Rosneft and PTC Surgutneftegaz, in which their stake is more than $33 \%$. The amendment could have an impact on the activity of every international company participating in joint energy projects with Russia because the term "United States person" includes companies having representative bodies in the United States. The foreign projects of Rosneft and Lukoil, introduced in Table 1, are potentially at risk.

The amendment reinforces the U.S.'s aim to ensure that equipment and services provided for joint external projects with Russian companies falling under the export and re-export ban will be used for the purpose intended and not for complex exploration projects in Russia. In the meantime, despite the new the executive order the Sanctions Act still contains loopholes, as projects on Russian territory in which a stake of less than $33 \%$ is held by sanctioned Russian companies are not subject to the sanctions.

The act allows for the possibility of sanctions in the form of restrictions on the supply of American goods and technologies as well as on funding from the U.S. for companies contributing to Russian export pipeline projects. 
Table 1. Foreign Projects of Rosneft and Lukoil Under Potential Risk Due to Sanctions

\begin{tabular}{|c|c|c|}
\hline Company & Lukoil & Rosneft \\
\hline \multirow[t]{2}{*}{$\begin{array}{l}\text { Latin } \\
\text { America }\end{array}$} & & $\begin{array}{l}\text { Brazil } \\
\text { Project Solimoes } \\
\text { (100\% owned by Rosneft) }\end{array}$ \\
\hline & & $\begin{array}{l}\text { Venezuela } \\
\text { 1. Carabobo-2, Carabobo-4 projects } \\
\text { (JV Petrovictoria) } \\
\text { (Rosneft share }-40 \% \text { ); } \\
\text { 2. Project Junin-6 } \\
\text { (JV Petromiranda) (Rosneft share }-40 \% \text { ); } \\
\text { 3. JV Petroperija } \\
\text { (Rosneft share }-40 \%) \text {. }\end{array}$ \\
\hline $\begin{array}{l}\text { European } \\
\text { Region }\end{array}$ & $\begin{array}{l}\text { Romania } \\
\text { Project Trident (Lukoil share - 72\%) }\end{array}$ & \\
\hline \multirow[t]{2}{*}{$\begin{array}{l}\text { Africa } \\
\text { Region }\end{array}$} & $\begin{array}{l}\text { Ghana } \\
\text { Project Deepwater Tano/Cape Three Points } \\
\text { (Lukoil share }-38 \% \text { ) }\end{array}$ & \\
\hline & $\begin{array}{l}\text { Côte d'Ivoire } \\
\text { Project CI-401 (Lukoil share }-56.66 \%) \text {; } \\
\text { Project CI-205 (Lukoil share }-63.0 \%)\end{array}$ & \\
\hline CIS & & $\begin{array}{l}\text { Abkhazia } \\
\text { Development of the Gudautsky area in the } \\
\text { Abkhazian sector of the Black Sea } \\
\text { (Rosneft share - 51\%) }\end{array}$ \\
\hline $\begin{array}{l}\text { Asia-Pacific } \\
\text { Region }\end{array}$ & & $\begin{array}{l}\text { Vietnam } \\
\text { Block } 06.1 \text { (Rosneft share - 35\%) }\end{array}$ \\
\hline
\end{tabular}

Source: Lukoil [2016], Rosneft [2016].

The new act also prohibits investment, sale or leasing involving goods, services, technology, information and support for construction, modernization and repair of Russian export energy pipelines which have a fair market value of more than \$1 million or an aggregate market value of $\$ 5$ million or more during a 12-month period.

The amendment serves to undermine Russian energy resource supplies in Europe and is aimed at the disruption of work on projects such as Nord Stream 2 and Turkish Stream. European oil and gas majors, including Royal Dutch Shell, Engie, Wintershall, OMV and Uniper, are involved in implementation of Nord Stream 2. The assessed value of the project is about $\$ 10$ billion and part of the funding has already been invested by foreign partners. Furthermore, all the vessels for laying undersea pipeline are owned by the European entities.

Within Turkish Stream, the Swiss Allseas, which has laid pipeline in the Black Sea shallow waters, falls under the sanctions. The company also takes part in laying further 
deepwater pipeline with technologies that are currently unavailable to Russia. Allseas' withdrawal from the project would negatively impact its future realization.

It should be noted that commissioning the pipeline on time, that is by 2019 , is of high importance for Russia in the context of the current round of negotiation with Ukraine to reach agreement on Russia's natural gas transit, which expires in late 2019.

The new restrictions could also concern infrastructural projects, including Baltic LNG, involving cooperation between Shell and Gazprom; Nord Stream, involving cooperation among Gazprom, Wintershall, Uniper, Gasunie and Engie; Blue Stream, involving cooperation between Eni and Gazprom; the pipe-building Caspian Pipeline Consortium involving Shell, Eni and Rosneft; and the construction of the South Caucasus Pipeline by BP and Lukoil.

The amendment sparked a backlash in Europe and is considered by a number of political leaders and companies to be an effort to undermine the energy security of European countries and to significantly impair business. It is quite evident that the main strategic goal of the restriction is the desire of the U.S. to possess the largest gas market in Europe by removing its key competitor - Russia - and by coercing European countries to import costly American liquefied natural gas, which requires an additional investment of 1 trillion euros in infrastructural projects.

There is every reason to believe that European countries would nevertheless take actions necessary to protect their interests aimed at economic and energy security preservation. Indirect evidence of this may be the Europeans' agreement to construct Nord Stream 2. Currently, virtually all European countries with territorial sea crossed by the pipeline agreed on its construction. Denmark is the last expected to sign the necessary authorizing documents.

While analyzing the new act, it has to be mentioned that the text contains the phrase "the president shall" instead of "the president must," which attaches a fundamentally different strength and greatly augments uncertainty as to law enforcement practice. As a result, at the moment the partners of Russian companies do not have a clear understanding as to whether their activity falls under the sanctions in case of participation in one joint project or another. Further, new potential risks for foreign companies arising from the implementation of large energy projects of strategic importance jointly with Russians could be viewed as unjustifiable. This would negatively influence ongoing effective practical bilateral and multilateral cooperation.

Together with this, while reacting to the sanctions and being forced to rearrange their strategic plans, the largest Russian oil and gas companies continue to maintain successful investment activity in foreign markets. Analysis of the investment activity of the Russian energy majors in the important foreign strategic markets over the period from the first restrictive documents to the present follows below. 


\section{Lukoil Capital Expansion Abroad in the Period Under Sanctions, 2015-2017}

Hydrocarbon reserves and the ramp-up of production volume in regions and countries which are preferred for their prospective development of the company remained one of the key strategic targets of Lukoil in 2015-2017. At the same time, the company restructured its foreign assets and optimized its petrochemical business segment.

The reorganization of Lukoil Overseas, Lukoil's subsidiary engaged in oil and gas deposit exploration and development outside Russia, was an important event in 2015. As defined by the company's formal documents, improved competitiveness, the introduction of international management standards, reduced offshore jurisdiction, as well as country and tax risk mitigation were the goals of the reorganization.

The company has been divided into three large management centres in Dubai, Houston and Tashkent, with the headquarters in Vienna. All projects in the Middle East and Africa have come under the management of Lukoil International Services B.V, with an office in Dubai. The Houston subdivision operates in Central Asia and North America, while the Tashkent one works with the company's projects on the territory of the CIS. Despite a complex external political and economic situation and the actual risks related to the new anti-Russian sanctions imposed by the U.S. in 2017, the company continues to launch new energy projects in new countries.

In February 2015, a decree by Cameroon's president authorized a deal with Lukoil which allows the company to join the project on the exploration of the Etinde field, located in Cameroon's offshore waters in the Gulf of Guinea (West Africa), in which Lukoil holds a 30\% stake. The deal was closed in March. In July, the company entered the Mexican market, having acquired a 50\% stake in the Amatitlán block exploration project. In September, the company officially joined the offshore project in OML-140 block in Nigeria (West Africa) with a 45\% stake [Lukoil, 2015; 2016]. In October, the deal to join the deepwater project in the Tano block - Deepwater Tano Cape Three Points in Ghanaian offshore waters in the Gulf of Guinea - where the company's stake is $38 \%$, was finalized. Moreover, in the near future Lukoil plans to explore Iran's Mansouri and Ab-Teymur deposits.

However, since 2015 there has been a downward trend in the company's foreign capital expenditures (calculated in dollars at the average rate over each year) in the segment of exploration and production. In 2015, the size of capital investment amounted to $\$ 3.2$ billion, having fallen by $14 \%$ over a year, in 2016 and 2017 , it decreased by $30 \%$ to $\$ 2.3$ billion and by $3 \%$ to $\$ 2.2$ billion, respectively (Fig. 1 ).

On the one hand, the fall in capital expenditure in foreign projects is partly related to the completion of a range of important stages of West Qurna 2 field infrastructure development and stages of exploration drilling in projects in Cameroon, Nigeria and Romania, as well as withdrawal from a number of projects which did not prove successful. 


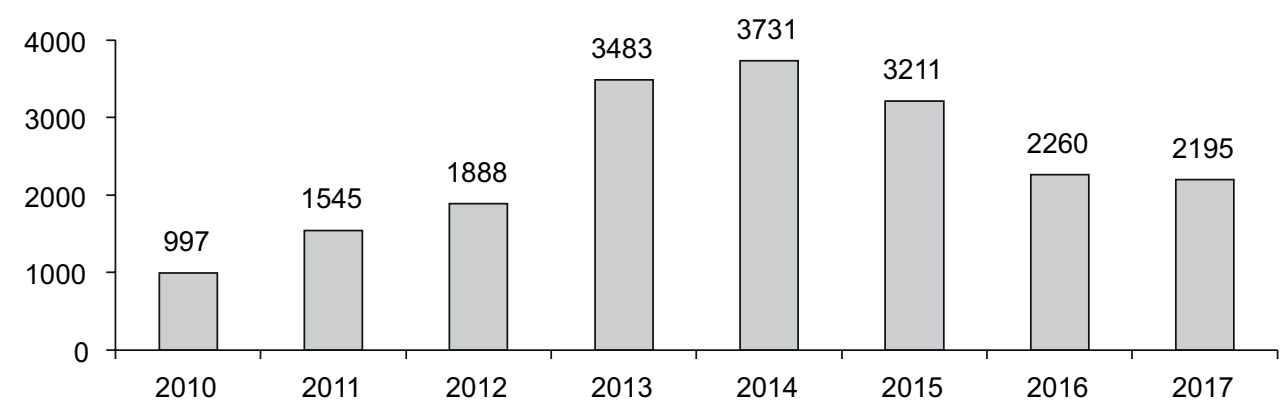

Fig. 1. Lukoil Capital Expenditures on Exploration and Production in the Development of Foreign Projects, 2010-2017*

* At an average exchange rate of 61 roubles per dollar in 2015, 67 roubles per dollar in 2016 and 58.4 roubles per dollar in 2017.

Source: Consolidated Financial Statements IFRS for 2010-2017, Managements' Discussion \& Analysis of Financial Condition and Results of Operations for 2010-2017 [Lukoil, c. a.].

On the other hand, the decrease is partly related to the complex economic and political situation and the prolonged and newly imposed anti-Russian sanctions. Investments in projects in Iraq in 2015 amounted to $\$ 736$ million and declined by $49 \%$ (over a year) to $\$ 295$ million in 2016 (60\% less compared to the previous year), and to \$241 million in 2017 (18.3\% less than in the previous year) (Fig. 2) (See Consolidated Financial Statements IFRS for 2010-2017 [Lukoil, c. a.]).

This was evident first in the West Qurna 2 project where capital expenditures were significantly reduced. The decline, however, is first explained by the completion of field infrastructure development. Since 2014 oil has been produced on the field. In 2017, the company reported that the project capital investments had been paid off.

However, it should be noted that due to a fall in oil prices the Iraqi government requested that Lukoil not increase production to $\$ 1.2$ million barrels a day in 2017 as was initially planned, and instead to limit production to 400,000 barrels a day. That was particularly explained by the production sharing agreement which presupposed offsetting field exploration costs by oil produced. In the situation of relatively low oil prices, that is $\$ 65-\$ 70$ per barrel, the volume of compensation oil which should be offset to Lukoil by the Iraq party increased, since the flat fee under the contract was set out at the oil price of $\$ 110$ per barrel.

In 2015 Lukoil launched the Etinde project in Cameroon. In 2015 investments amounted to $\$ 131$ million and in 2016 they fell to $\$ 18$ million (86\% less compared to the previous year).

The capital expenditures in the Romanian projects demonstrated $189 \%$ growth in 2015, yet in 2016 growth was down $97 \%$, related mostly to withdrawal from the Rapsodia project on the Romanian shelf after unsuccessful exploratory research. Nonetheless, Lukoil stayed in Romania and continues to work on the Trident shelf project following the discovery of a new gas deposit in 2015 . 


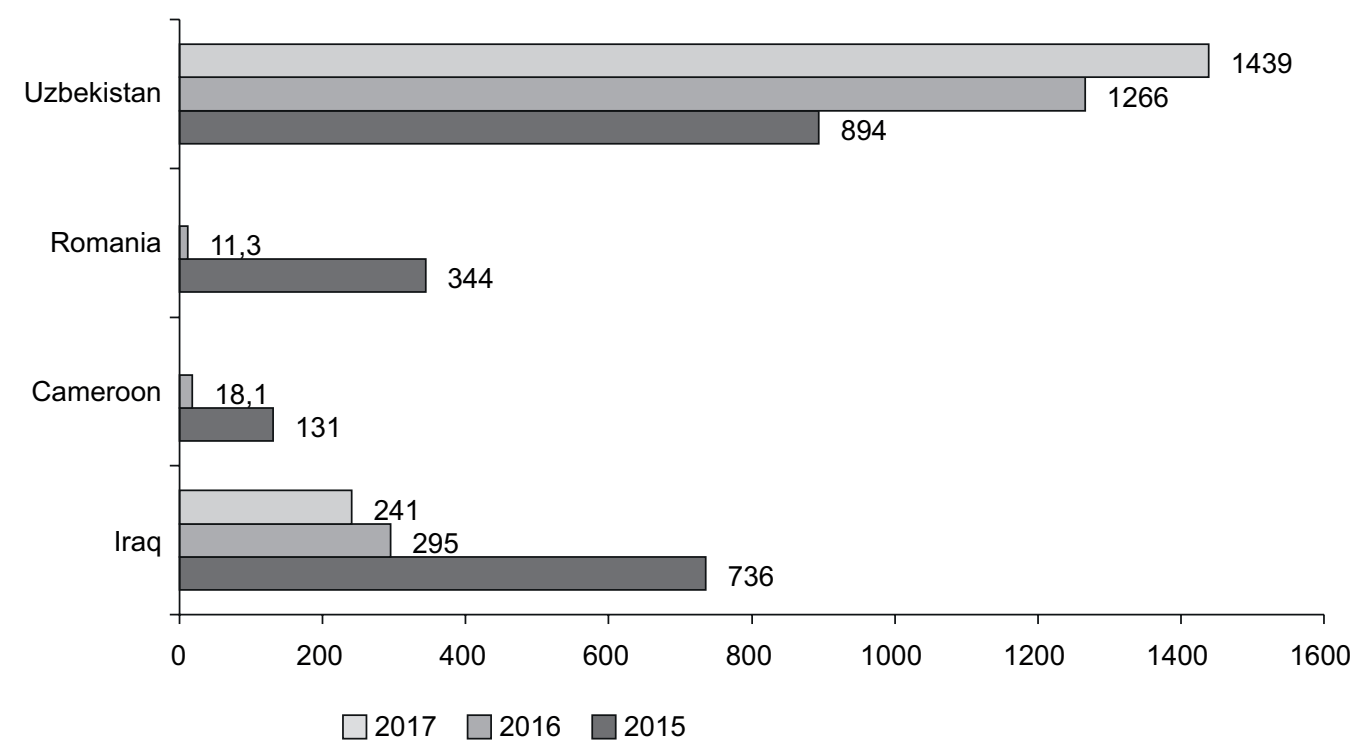

Fig. 2. Lukoil Capital Expenditures on Exploration and Production in New and Prospective Regions, 2015-2017*

* At an average exchange rate of 61 roubles per dollar in 2015, 67 roubles per dollar in 2016 and 58.4 roubles per dollar in 2017.

Source: Consolidated Financial Statements IFRS for 2010-2017, Managements' Discussion \& Analysis of Financial Condition and Results of Operations for 2010-2017 [Lukoil, c. a.].

Stable growth of capital expenditure in 2015-2017 was observed in the company's projects in Uzbekistan: in 2015 the company fixed a $6.7 \%$ growth rate, with a capital expenditure of $\$ 894$ million, increasing by $42 \%$ to $\$ 1.3$ billion in 2016 and by $13.7 \%$ to $\$ 1.5$ billion in 2017. In 2015 six wells were put into operation at the Dzharkuduk field within the framework of the South-Western Guissar project, and exploration at $\mathrm{Ku}-$ vachi Alat and North Shady fields of Kandym-Khausak-Shady-Kungrad started ahead of time (see Consolidated Financial Statements IFRS for 2010-2017 [Lukoil, c. a.]). In 2017 the preliminary gas-processing terminal and six gas-gathering stations were launched within the framework of the South-Western Guissar project, and as part of the Kandym project the first phase of Gas Processing Complex construction was completed.

Foreign capital expenditures in the refining, marketing and distribution segments declined as well, falling in $2014-2016$ by $68 \%$ to $\$ 256$ million. The fall was seen mostly in oil refineries and was caused by the completion of construction of the large heavy residue process complex in the oil refinery plant in Bulgaria (Fig. 3 and 4).

In 2015-2017, the company continued to implement the post-crisis strategy goals to diversify and optimize its distribution network. In 2015, Lukoil sold its petrol stations in Ukraine and Estonia, and in 2016-2017 sold its petrol stations in Poland, Latvia, 
Lithuania and Cyprus. As a result, whereas by the end of 2016 the company had 2,706 petrol stations abroad, by the end of 2017 there were only 2,649. Capital expenditure for international distribution network development over the 2015-2017 period amounted to $\$ 264$ million.

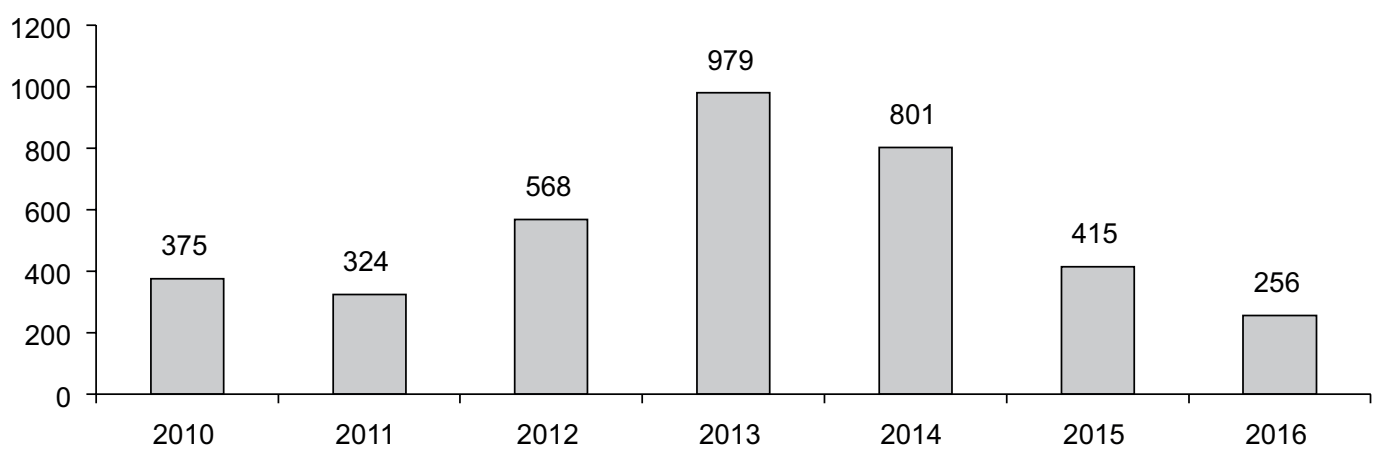

Fig. 3. Lukoil Foreign Capital Expenditures on Refining, Marketing and Distribution, 2010-2016*

* At an average exchange rate of 61 roubles per dollar in 2015 and 67 roubles per dollar in 2016.

Source: Consolidated Financial Statements IFRS for 2010-2016, Managements' Discussion \& Analysis of Financial Condition and Results of Operations for 2010-2016 [Lukoil, c. a.].

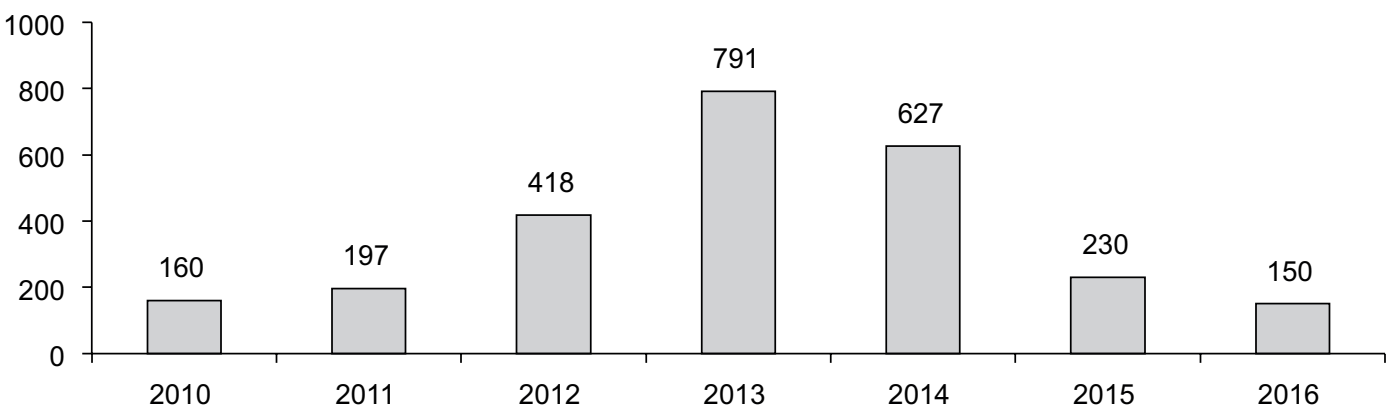

Fig. 4. Lukoil Capital Expenditures on the Development of Foreign Refineries, 2010-2017*

* At an average exchange rate of 61 roubles per dollar in 2015, 67 roubles per dollar in 2016 and 58.4 roubles per dollar in 2017.

Source: Consolidated Financial Statements IFRS for 2010-2017, Managements' Discussion \& Analysis of Financial Condition and Results of Operations for 2010-2017 [Lukoil, c. a.].

Experts estimate that the sell-out by Lukoil of all foreign oil refining and distribution assets was a consequence of the new sanctions package against Russia. Lukoil management, in turn, emphasizes that although the company suffers difficulties raising external financial resources, the sell-out of its foreign assets and sanctions only demon- 
strates a standard response to a market situation change and results from the company's reorganization and asset optimization.

\section{Rosneft Capital Expansion Abroad in the Period Under Sanctions, 2015-2017}

Currently, Rosneft's major focus is on the domestic market; however, the company plans to increase the share of its foreign projects and strengthen its presence in the prospective regions which can provide real opportunities for the company. At the same time, Rosneft's senior management notes that extending the scope and geography of the business will require an increase of outward foreign investment amounts and will be accompanied by a range of difficulties, including those related to sanctions imposed against Russia and strengthened in 2017.

The period from 2015-2017 was marked for Rosneft by the increase of its foreign expansion and planned implementation of already existing foreign projects in the field of hydrocarbon exploration and production and also in the field of refining. In October 2015, Rosneft, in partnership with ExxonMobil, won the tender and received the right to undertake exploration on the shelf of Mozambique with three licenses: A5-B, Z5-C and Z5-D. Some seismic activities have already started. Rosneft plans to finish offshore exploration not earlier 2021. Despite the fact that partnership between Rosneft and ExxonMobil collapsed in Russia, it has continued to develop abroad [Rosneft, 2015a].

In May 2016 Rosneft increased its stake in the Petromonagas joint venture, which implements extra-heavy crude oil production projects in Venezuela, to $40 \%$ [Rosneft, 2015b; 2016a]. In October, Rosneft increased its activities, including foreign ones, by closing the deal on acquisition of the government's stake in Bashneft Public Joint Stock Company representing $50.08 \%$ of its charter capital. The company received a positive synergetic effect from this deal. The capitalization and stock prices of the company increased, as did the production of liquid hydrocarbon (by 10\%) and refining throughput (by 20\%). The quality of refining assets was also improved and the company gained access to additional infrastructure and new hydrocarbon production regions and sales markets [Rosneft, 2015b; 2016a]. In December, Rosneft and the state-run oil company of the Republic of Cuba, Union CubaPetroleo (CUPET) signed an agreement to enhance oil production at Varadero-East Central Block. Rosneft continues to consolidate its position in the Latin American energy market where a number of large projects are being implemented in Venezuela and Brazil (Solimoins project).

In October 2017, Rosneft invested $\$ 1.125$ billion in the acquisition of a $30 \%$ share in the project of the Italian company Eni for the development of the large gas field Zohr, located on the deepwater shelf of Egypt. Shares in the project are distributed as follows: Eni owns 60\%, BP owns 10\% and Rosneft owns 30\%. Participation in this project will provide Rosneft with additional experience in the development of offshore fields and will strengthen the country's position in the African region. The Zohr field accounts for about $30 \%$ of Egypt's gas reserves. 
It must be pointed out that Rosneft considers the Middle East to be a prospective market, taking into account the large resource base available on its territory. After acquiring controlling shares of Bashneft company, Rosneft has obtained access to work in Iraq. Moreover the company expects enhanced cooperation with this country in the near future. At the moment, Rosneft is the operator for exploration and development of hydrocarbons in the context of the Block 12 project in Iraq, located in the provinces of Najaf and Muthanna. Drilling of the first exploratory well, Salman-1, began in February 2017. Rosneft controls $70 \%$ of the project and the remaining share $(30 \%)$ is controlled by the British company Premier Oil.

At the beginning of 2017, the company signed an agreement for three years with the government of Kurdistan for the purchase of oil valued at \$1 billion. Later, in the summer, agreements on Rosneft's access to export pipelines passing through the territory of Kurdistan with a capacity of 700,000 barrels per day was reached. In October, the sides signed documents on the development of five oil blocks, including those located in Kirkuk, which remains a disputed territory. Due to the fact that the government of Kurdistan has the right to conclude agreements with foreign partners without the permission of the central authorities only on the territory of the autonomy itself, the agreements reached between Rosneft and Kurdistan are controversial, and their implementation will largely depend on the negotiation process between the governments of Russia and Iraq.

Rosneft is also considering the possibility of entering the Iranian market. The company is interested in mutually beneficial cooperation with Iranian oil companies on projects for the development of large oil and gas fields with a proven onshore and offshore resource base, as well as entering geological exploration units after examination of their geological structure and resource potential.

During the period 2015-2017 Rosneft has significantly expanded its presence in the Asia-Pacific market. In 2016, through the acquisition of Bashneft, Rosneft gained access to the Myanmar energy market within the framework of the development and exploration project of the EP-4 unit located in the central oil and gas basin of Myanmar. Rosneft also plans to enter the Indonesian market. In May, Rosneft signed an agreement with the Indonesian company Pertamina on the construction by 2022 of a Tuban oil refinery in Indonesia with a capacity of about 15 million tons per year and costing about $\$ 13$ billion. According to the agreement, Rosneft would control $45 \%$ of the project. The construction of such facility would allow the direct supply of Russian oil to Indonesian partners without intermediaries, and would also ensure greater economic efficiency of oil refining in Indonesia.

In August 2017, Rosneft implemented a deal to buy the second-largest power plant in India. The company purchased a $49 \%$ share of Essar Oil Limited (EOL), thus obtaining a share in the high-tech oil refinery Vadinar in the city of Vadinar (state Gujarat) with a capacity of 20 million tons and a processing depth estimated at $95.5 \%$ [Rosneft, 2016b]. 
Rosneft actively involves partners from the Asia-Pacific region to collaborate in joint projects in the territory of Eastern Siberia in order to provide them with an additional volume of investment, as well as for the purpose of risk sharing.

During the period 2015-2017 Rosneft continued to expand its marketing assets, entering new foreign markets. In November 2015 the company acquired a 100\% share of the Armenian company Petrol Market LLC for $\$ 40$ million, having received a network of filling stations and a tank farm in Armenia.

Moreover in 2017 Rosneft received additional retail assets for foreign oil sales in India after the acquisition of a share in EOL, which has an extensive retail distribution network in India that contains 3,500 filling stations. At the same time, the company sold a number of inefficient marketing assets, including those located in Ukraine.

Table 2. Structure and Geography of Lukoil and Rosneft Foreign Expansion as of 2017

\begin{tabular}{|c|c|c|}
\hline Company & Lukoil & Rosneft \\
\hline & Expansion Exploration and Production & \\
\hline \multirow[t]{2}{*}{ The Middle East } & $\begin{array}{l}\text { Iraq } \\
\text { Project West Qurna-2 } \\
\text { Project Unit-10 }\end{array}$ & $\begin{array}{l}\text { Iraq } \\
\text { Unit-12 }\end{array}$ \\
\hline & $\begin{array}{l}\text { Saudi Arabia } \\
\text { Project Unit A }\end{array}$ & \\
\hline \multirow[t]{5}{*}{$\begin{array}{l}\text { Commonwealth of } \\
\text { Independent States } \\
\text { (CIS) }\end{array}$} & $\begin{array}{l}\text { Kazakhstan } \\
\text { Kukmol project } \\
\text { Karachaganak project } \\
\text { Tengiz project }\end{array}$ & $\begin{array}{l}\text { Kazakhstan } \\
\text { Kurmangazy project }\end{array}$ \\
\hline & $\begin{array}{l}\text { Uzbekistan } \\
\text { South-Western Hissar project } \\
\text { Kandym-Khauzak-Shady-Kungrad project } \\
\text { Aral project }\end{array}$ & \\
\hline & $\begin{array}{l}\text { Azerbaijan } \\
\text { Project Shah Deniz }\end{array}$ & $\begin{array}{l}\text { Azerbaijan } \\
\text { Interested to take part in development of } \\
\text { the Absheron project }\end{array}$ \\
\hline & & $\begin{array}{l}\text { Abkhazia } \\
\text { The project for the development of the } \\
\text { Gadautsky license area on the Black Sea } \\
\text { shelf }\end{array}$ \\
\hline & & $\begin{array}{l}\text { Turkmenistan } \\
\text { Project Unit } 21\end{array}$ \\
\hline \multirow[t]{2}{*}{ European Region } & $\begin{array}{l}\text { Romania } \\
\text { Trident }\end{array}$ & \\
\hline & $\begin{array}{l}\text { Norway } \\
\text { Project PL } 708 \\
\text { Project PL } 719\end{array}$ & $\begin{array}{l}\text { Norway } \\
\text { Project PL } 713 \text { for the development of } \\
\text { the license area on the Norwegian shelf } \\
\text { in the Barents Sea }\end{array}$ \\
\hline African Region & $\begin{array}{l}\text { Egypt } \\
\text { Project Meleiha } \\
\text { Project WEEM } \\
\text { Project WEEM Extension }\end{array}$ & $\begin{array}{l}\text { Egypt } \\
\text { Project Zohr (joined in 2017) }\end{array}$ \\
\hline
\end{tabular}




\begin{tabular}{|c|c|c|}
\hline Company & Lukoil & Rosneft \\
\hline \multirow[t]{5}{*}{ African Region } & $\begin{array}{l}\text { Côte d'Ivoire } \\
\text { Project CI-401 } \\
\text { Project CI-205 }\end{array}$ & \\
\hline & $\begin{array}{l}\text { Cameroon } \\
\text { Project Etinde }\end{array}$ & \\
\hline & $\begin{array}{l}\text { Ganna } \\
\text { Project Deep Water Tano Cape Three } \\
\text { Points }\end{array}$ & \\
\hline & $\begin{array}{l}\text { Nigeria } \\
\text { OML-140 Nsiko } \\
\text { OML-140 BSWAp }\end{array}$ & \\
\hline & & $\begin{array}{l}\text { Mozambique } \\
\text { Licensed areas A5-B, Z5-C and Z5-D }\end{array}$ \\
\hline \multirow[t]{4}{*}{ Latin America } & & $\begin{array}{l}\text { Venezuela } \\
\text { Project Carabobo-2,4 (JV Petrovictoria) } \\
\text { Project Junin-6 (JV PetroMiranda) } \\
\text { JV PetroMonagas } \\
\text { JV Boqueron } \\
\text { JV Petroperiha }\end{array}$ \\
\hline & & $\begin{array}{l}\text { Brasil } \\
\text { Solimoes Project }\end{array}$ \\
\hline & & $\begin{array}{l}\text { Cuba } \\
\text { Unit } 37 \\
\text { Varadero }\end{array}$ \\
\hline & $\begin{array}{l}\text { Mexico } \\
\text { Amatitlán }\end{array}$ & \\
\hline North America & & $\begin{array}{l}\text { Canada } \\
\text { Cardium Project }\end{array}$ \\
\hline \multirow[t]{2}{*}{ Asia-Pacific Region } & & $\begin{array}{l}\text { Vietnam } \\
\text { Unit 06,1 (the Lantai and Lando fields) } \\
\text { Unit 05,3/11 } \\
\text { The Nam Con Son Pipeline }\end{array}$ \\
\hline & & $\begin{array}{l}\text { Myanmar } \\
\text { Unit EP-4 }\end{array}$ \\
\hline \multicolumn{3}{|c|}{ Foreign Oil Refineries } \\
\hline European Region & $\begin{array}{l}\text { Romania } \\
\text { The Romanian Petrotel Ploiesti refinery }\end{array}$ & \\
\hline \multirow[t]{4}{*}{ European Region } & $\begin{array}{l}\text { The Netherlands } \\
\text { Zeeland refinery }\end{array}$ & \\
\hline & $\begin{array}{l}\text { Bulgaria } \\
\text { Burgas refinery }\end{array}$ & \\
\hline & $\begin{array}{l}\text { Italy } \\
\text { ISAB refinery }\end{array}$ & $\begin{array}{l}\text { Italy } \\
\text { Sarroch refinery }\end{array}$ \\
\hline & & $\begin{array}{l}\text { Germany } \\
\text { Gelsenkirchen refinery } \\
\text { Bayernoil refinery } \\
\text { MiRO refinery } \\
\text { PCK Raffinerie GmbH }\end{array}$ \\
\hline
\end{tabular}




\begin{tabular}{|l|l|l|}
\hline \multicolumn{1}{|c|}{ Company } & \multicolumn{1}{|c|}{ Lukoil } & \multicolumn{1}{c|}{ Rosneft } \\
\hline $\begin{array}{l}\text { Commonwealth of } \\
\text { Independent States } \\
\text { (CIS) }\end{array}$ & $\begin{array}{l}\text { Belarus } \\
\text { Mozyrsk refinery }\end{array}$ \\
\hline Asia-Pacific Region & $\begin{array}{l}\text { China } \\
\text { Tianjin refinery (stage of technical back- } \\
\text { stopping for the project) }\end{array}$ \\
\hline & $\begin{array}{l}\text { India } \\
\text { Vadinar refinery (joined the project in } \\
2017)\end{array}$ \\
\hline & $\begin{array}{l}\text { Indonesia } \\
\text { Tuban refinery (implementation is } \\
\text { planned) }\end{array}$ \\
\hline Foreign Distribution Network & $\begin{array}{l}\text { 2,706 pieces, or 51\% of the total number of } \\
\text { the company's petrol stations }\end{array}$ \\
\hline $\begin{array}{l}\text { Overseas Petrol } \\
\text { Stations }\end{array}$ & \\
\hline
\end{tabular}

Source: Lukoil [2016; 2017], Rosneft [2016a, 2017].

\section{Conclusion}

Despite the strengthening of anti-Russian sanctions aimed at destabilizing the Russian fuel and energy complex, currently the country's largest oil and gas TNCs continue to effectively expand their capital abroad and strengthen their presence in the energy markets of the most promising regions, especially in the exploration and production segments. However, it should be noted that the new restrictions imposed by the U.S. threaten the implementation of joint foreign energy projects on production and energy infrastructure which involve technologies and services provided especially by foreign companies, not only in Russia, but also abroad. The newly implemented sanctions may force foreign companies to abandon the projects mentioned above in order to protect their assets, because in theory such companies need to exclude U.S. dollar settlements, at least, and to completely exclude ties with U.S. entities, even through affiliated structures.

Currently, within a reasonable time frame (less than four years), the impact of sanctions on the international activity of the largest Russian oil and gas companies is not so tremendous to significantly adjust their long-term development programmes. However, the sanctions have a "cumulative effect," and the negative consequences may be fully assessed only in the long term. The main goal of the sanctions against Russia is to block opportunities for the future growth and development of Russia's key economic sectors.

The results are mixed. On the one hand, additional sanctions make Russia an "unattractive partner" by restricting the international oil and gas expansion of Russian energy companies and by limiting foreign funding for joint projects. These measures narrow Russia's ability to obtain modern technologies. On the other hand, the 
sanctions have a stimulating impact on the accelerated implementation of the import substitution programme and the development of a domestic base for the production of modern energy technologies. Moreover, although the sanctions are officially directed against Russia, they are to some degree extraterritorial and their application will have a direct negative effect on all partners of Russian companies, affecting their business interests and creating additional costs and losses. In the modern world it is hardly possible to cause maximum damage to one side while minimally affecting other players in the market. The current stage of globalization is characterized by a large number of cooperative and other types of ties which are difficult to foresee and calculate.

That is why the position of the western partners and, above all, significant European oil and gas market players, will largely determine the structure and prospects for the development of the world oil and gas market and also the participation of Russian companies in the exploration of foreign energy resources deposits, the construction of refining and distribution capacities and the search for new prospective partners from the developing world.

Protecting the interests of the country's business has been and remains the main task of the Russian state in the face of sanctions implemented on the part of the leading western developed countries.

\section{References}

Lukoil (c. a.) Financial Results. Available at: http://www.lukoil.ru/InvestorAndShareholderCenter/ReportsAndPresentations/FinancialReports (accessed 19 January 2019). (In Russian)

Lukoil (2015) Annual Report. Available at: http://www.lukoil.ru/FileSystem/9/289047.pdf (accessed 20 March 2018) (accessed 19 January 2019). (In Russian)

Lukoil (2016) Annual Report. Available at: http://www.lukoil.ru/FileSystem/9/289047.pdf (accessed 19 January 2019). (In Russian)

Lukoil (2017) Annual Report. Available at: http://www.lukoil.ru/FileSystem/9/289721.pdf (accessed 19 January 2019). (In Russian)

Rosneft (2015a) Rosneft and ExxonMobil Recognized Winners in Licensing Round in Mozambique. Press Release, 29 October. Available at: https://www.rosneft.ru/press/releases/item/176645/ (accessed 19 January 2019). (In Russian)

Rosneft (2015b) Annual Report. Available at: https://www.rosneft.ru/upload/site1/document_file/a_report_2015.pdf (accessed 19 January 2019). (In Russian)

Rosneft (2016a) Annual Report. Available at: https://www.rosneft.ru/upload/site1/document_file/a_report_2016.pdf (accessed 19 January 2019). (In Russian)

Rosneft (2016b) Rosneft Acquires 49\% of Essar Oil Limited. Press Release, 15 October. Available at: https://www.rosneft.ru/press/releases/item/184097/ (accessed 19 January 2019). (In Russian)

Rosneft (2017) Annual Report. Available at: https://www.rosneft.ru/upload/site1/document_file/a_report_2017.pdf (accessed 19 January 2019). (In Russian)

United States Treasury (2014a) Directive 2 Under Executive Order 13662. Office of Foreign Assets Control, 12 September. Available at: https://www.treasury.gov/resource-center/sanctions/Programs/Documents/eo13662_directive2.pdf 
United States Treasury (2014b) Directive 4 Under Executive Order 13662. Office of Foreign Assets Control, 12 September. Available at: https://www.treasury.gov/resource-center/sanctions/Programs/Documents/eo13662_directive4.pdf

United States Treasury (2017) Countering America's Adversaries Through Sanctions Act H. R. 3364. Available at: https://www.treasury.gov/resource-center/sanctions/Programs/Documents/hr3364_pl11544.pdf (accessed 12 November 2017). 


\title{
Влияние антироссийских санкций США на зарубежную экспансию крупнейших российских нефтегазовых ТНК ПАО «Лукойл» и ПАО «Роснефть» (инвестиционная стратегия крупнейших российских компаний нефтегазового сектора в условиях ужесточения санкционных ограничений $)^{1}$
}

\author{
Н.М. Иванова, С.Н. Лавров
}

\begin{abstract}
Иванова Наталья Михайловна - к.э.н., начальник отдела двустороннего сотрудничества департамента международной деятельности ФГБУ «Российское энергетическое агентство»; Российская Федерация, Москва, ул. Щепкина, д. 40-1; E-mail: na_iv@mail.ru

Лавров Сергей Николаевич - д.э.н., профессор, руководитель секции международного бизнеса департамента мировой экономики факультета мировой экономики и мировой политики НИУ «Высшая школа экономики»; Российская Федерация, Москва, ул. Шаболовка, д. 31, стр. 23; E-mail: lavrovsn@mail.ru

Статья посвящена вопросу воздействия антироссийских санкций, введенных США, включая новые санкционные меры от 2 августа 2017 г., на зарубежнню инвестиционную деятельность крупнейших российских нефтегазовых ТНК - ПАО «Лукойл» и ПАО «Роснефть» в частности. Авторы раскрывают содержсание обновленных санкционных ограничений, выявляют возможные последствия данных ограничений для развития ТЭК России и зарубежной экспансии капитала крупнейших нефтегазовых ТНК, анализируют зарубежную инвестиционную деятельность российских нефтегазовых ТНК ПАО «Лукойл» и ПАО «Роснефть» в санкционный период.
\end{abstract}

Ключевые слова: санкции; нефтегазовый сектор России; зарубежная инвестиционная деятельность российских нефтегазовых ТНК; ПАО «Лукойл»; ПАО «Роснефть»

Для цитирования: Иванова Н.М., Лавров С.Н. (2019) Влияние антироссийских санкций США на зарубежную экспансию крупнейших российских нефтегазовых ТНК ПАО «Лукойл» и ПАО «Роснефть» (инвестиционная стратегия крупнейших российских компаний нефтегазового сектора в условиях ужесточения санкционных ограничений) // Вестник международных организаций. Т. 14. № 1. С. 126-144. DOI: 10.17323/19967845-2019-01-08

\section{Источники}

ПАО «Лукойл» (2015) Годовой отчет ПАО «Лукойл» за 2015 г. Режим доступа: http://www.lukoil.ru/InvestorAndShareholderCenter/ReportsAndPresentations/AnnualReports (дата обращения: 20.03.2018).

ПАО «Лукойл» (2016) Годовой отчет ПАО «Лукойл» за 2016 г. Режим доступа: http://www.lukoil.ru/ FileSystem/9/289047.pdf (дата обращения: 19.04.2018).

ПАО «Лукойл» (2017) Годовой отчет ПАО «Лукойл» за 2017 г. Режим доступа: http://www.lukoil.ru/InvestorAndShareholderCenter/ReportsAndPresentations/AnnualReports (дата обращения: 01.04.2018).

ПАО «Лукойл» (б. г.) Финансовые результаты. Режим доступа: http://www.lukoil.ru/InvestorAndShareholderCenter/ReportsAndPresentations/FinancialReports (дата обращения: 01.04.2018).

${ }^{1}$ Статья поступила в редакцию в июне 2018 г. 
ПАО «НК «Роснефть» (2015b) Годовой отчет «Роснефть» за 2015 г. Режим доступа: https://www.rosneft. ru/upload/site1/document_file/a_report_2015.pdf (дата обращения: 14.05.2018).

ПАО «НК «Роснефть» (2015a) «Роснефть» и ExxonMobil признаны победителями в лицензионном раунде в Мозамбике. Режим доступа: https://www.rosneft.ru/press/releases/item/176645/ (дата обращения: 14.05.2018).

ПАО «НК «Роснефть» (2016а) Годовой отчет ПАО «НК «Роснефть» за 2016 г. Режим доступа: https:// www.rosneft.ru/upload/site1/document_file/a_report_2016 (дата обращения: 14.05.2018).

ПАО «НК «Роснефть» (2016b) «Роснефть» приобретает 49\% Essar Oil Limited. Режим доступа: https:// www.rosneft.ru/press/releases/item/184097/ (дата обращения: 01.04.2018).

ПАО «НК «Роснефть» (2017) Годовой отчет ПАО «НК «Роснефть» за 2017 г. Режим доступа: https:// www.rosneft.ru/upload/site1/document_file/a_report_2017.pdf (дата обращения: 01.04.2018).

United States Treasury (2014a) Directive 2 Under Executive Order 13662. Office of Foreign Assets Control, 12 September. Available at: https://www.treasury.gov/resource-center/sanctions/Programs/Documents/ eo13662_directive2.pdf (дата обращения: 12.11.2017).

United States Treasury (2014b) Directive 4 Under Executive Order 13662. Office of Foreign Assets Control, 12 September. Available at: https://www.treasury.gov/resource-center/sanctions/Programs/Documents/ eo13662_directive4.pdf (дата обращения: 12.11.2017). 